\title{
Maracatu Rural: Improvisation as a Social and Cultural Practice
}

\author{
Stefan Weghuber
}

Introduction

Maracatu Rural is a type of folk play with improvised verses performed in Pernambuco, a state in northeastern Brazil. This verbal improvisation is regarded both as a national heritage and a highly valued cultural expression. When we hear the term improvisation, we usually think of unstructured, free, and virtuosic music, mostly in a US context. Given this understanding, I entered the field of Brazilian improvisation expecting to encounter loose words that come to the poet's mind through intuition and personal genius-but the opposite is the case. Improvisation in Pernambuco encompasses a wholly different social and cultural understanding of the term:

1. Pernambuco is embedded in a performative context defined by poet and audience, where how something is said is more important than the exact content.

2. Improvisation means mainly that an audience hears a verse for the first time, and that it is not repeated twice to the same people.

3. Sung verses are determined by exact metrics, where the number of syllables and the rhythmic pattern structure the lyrics and corresponding themes.

4. Improvisation is a social action in which artists make personal and sometimes risky decisions.

5. The decision to improvise depends on the specific cultural context.

\section{A Short Overview of the History of Maracatu Rural}

\author{
"Poetry is correlated to the institutions of the society in which it is situated" (Finnegan 244).
}

Improvisation is closely related to many Brazilians' lives; it is a tool to "deal with scarce resources under hard conditions" (Stanyek 5), especially among the Afro-Brazilian population. Terms like jeitinho and gambiarra refer to the creative capacity to compensate for the disadvantages of material deprivation (5). Maracatu Rural was born under such conditions in the post-slavery sugar-cane economy of Pernambuco where a system of on-going paternalism still dominates the social and cultural dimensions of the art form. The organization of improvisation duels, for example, is dependent financially on local political or private sponsorships. The interest of the urban public in Maracatu Rural can be seen in a similar light as the favela tours in Rio, where the representation of creativity in poor areas reproduces social exclusion (9). Tourists are interested only in taking pictures of an assumed living past, not in engaging responsibly with the social conditions that inspire such rural cultural expressions.

The history of Maracatu Rural is part of a broader struggle for wider national recognition of Afro-Brazilian music. From its beginnings around 1900 until the 1970s, Maracatu Rural was composed of loose carnival groups who interacted mostly in the Zona da Mata, the outland of Pernambuco (Assis 22-34). Many myths originated in this period wherein various Maracatu groups (cruzeiro das bandeiras) often had violent fights with each other (Medeiros 62) and the singing was not improvised and consisted only of short verses repeated collectively (Silva 21-23). Due to the sugar cane crisis in the early 1990s, many rural workers migrated to the suburbs of Recife, where Maracatu became visible to other citizens (Assis 31). The resulting exchange of perspectives established new mediators and collaborators, leading to a truce between the different Maracatu groups (Medeiros 46) and a significant increase in the overall popularity of this genre. The Associação dos Maracatus de Baque Solto de Pernambuco, for example, now contains more than 90 official groups (agremiações) (Vicente 84-85). The visibly attractive caboclos de lança (Lance Warriors) have become one major symbol of Pernambucanian carnival and culture and can be found almost everywhere as merchandise (dolls, statues, stickers, t-shirts, and the like). Social movements like the mangue beat also contributed in the mid-1990s to the re-evaluation and promotion of the "traditional" styles of the Northeast. In 2000, the preservation of patrimônio vivo (living heritage) became law in Brazil (Sandroni 68). Since then, one can notice a certain folclorization: a relationship between popular culture and the state based on very strict traditional cultural expressions. Music from the Northeast is now seen as a source of Brazilian national identity, and its practitioners are celebrated for maintaining an important cultural legacy (Sandroni 63). 


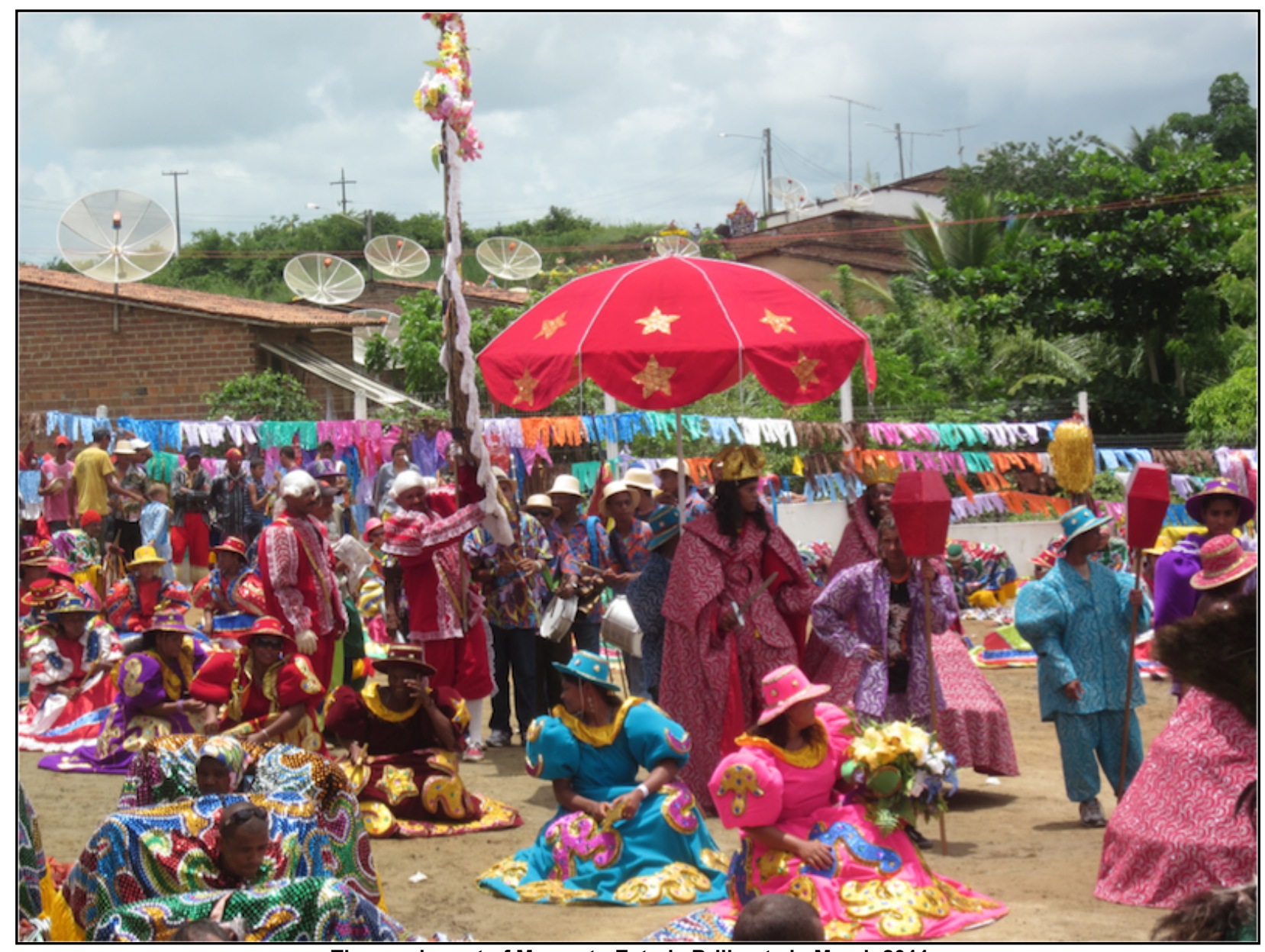

The regal court of Maracatu Estrela Brilhante in March 2011.

Maracatu poets construct their art form for outsiders, aware of the expectations and demands that are connected to the assumed exoticism of secret rituals and mystic codes that in part define Afro-Brazilian folk-play. To survive financially, they must fulfill these images in their lyrics while singing at the multicultural carnivals of Pernambuco, where many different folk-plays of the Northeast are marked as "exotic others." As noted by Ulf Hannerz in his analysis of global and local theatre, "competitive distinctiveness" is a feature of this art form: the more exotically attractive a play, the more successful it is (113).

Today, the poets of the Northeast are not the only producers of their cultural meanings; many people across Brazil, and even worldwide, have access to Maracatu through media such as Facebook and YouTube, and these musical expressions are in ever-greater demand due to their exotic cultural appeal. This popular, mediatized interaction is shaped by self-ascription and ascription by others, and always reflects power relations (Béhague, "Introduction" v). Although the use of digital cameras and sound recorders was once limited to outsiders, most Maracatu poets and groups now promote themselves through local radio stations and social networks, posting videos and lyrics to showcase their newest productions and recordings. ${ }^{1}$ Clips from improvisation duels, for example, are thus highlighted in social media either to pay homage to past events or to promote coming attractions. Such mechanical reproduction, however, cannot possibly capture every dimension of an all-night improvisation duel. Maracatu improvisatory practices are not adequately represented by these new technologies because of the importance in such a musical feast of the social context and the vivid exchanges between all involved. In addition, these media shortcuts tend to reproduce clichés about Pernambucan folk culture being exotic, an untouched relic of a long forgotten past. 


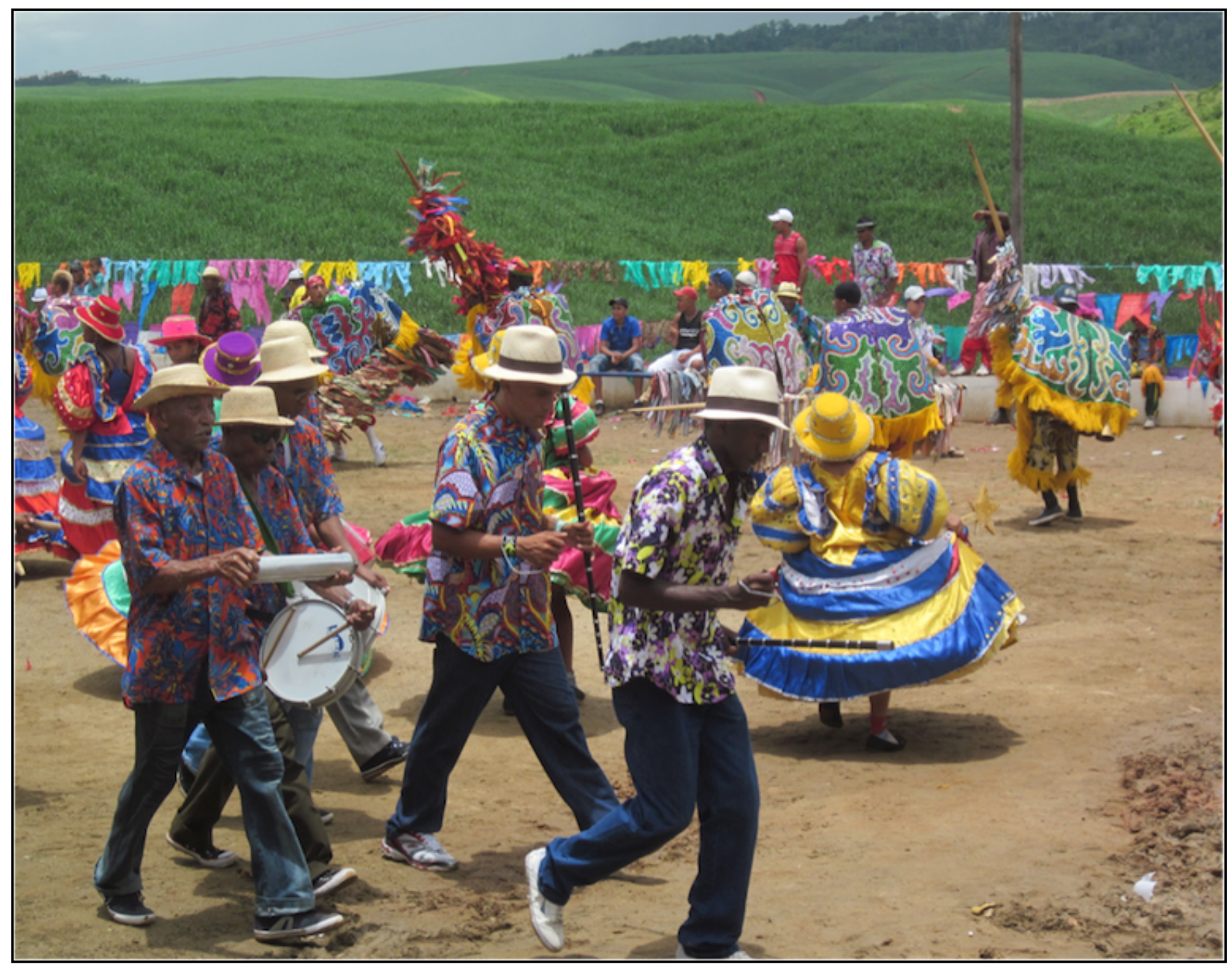

Mestre Barachinha of Estrela Brilhante with his Contramestre and Terno on an apresentação in Aliança. Encontro dos Maracatus (8 March 2011).

\section{'Verbal Art as Performance'}

“'Music itself' only exists in performance contexts and ... as performance is all we have, it should be our primary source of study" (Béhague, "Performance" 11).

To understand the improvisation of Maracatu Rural, it is important to consider poetry as a social practice within a performance setting. According to Baumann, improvising poets perform familiar exchanges of rhyme, harmony, and figurative language that audiences then evaluate, often more for their quality of expression than their underlying content (293-295). Public carnivals and more informal rural celebrations serve as the main settings for improvised performance. At such events, three dimensions of social practice should be considered: the poeta (poet), the poesía (poetry), and a público (audience) composed of diverse social agents.

Year after year, Maracatu Rural attracts more and more listeners unfamiliar with its improvisational protocols (mostly urban residents in Brazil, but also some tourists, journalists, and researchers), and their perspectives can greatly influence the cultural and thematic content of performances.

\section{Rules and Structure of Maracatu Rural Improvisation}

The performance of Maracatu Rural can be split into two parts where the improvisation of either the poets or the musicians and dancers dominates. During the vocal sections, which last 30-90 seconds, the instrumentalists remain 
silent and the dancers stand at ease. The mestre (lead singer) signals the end of his verbal solo by blowing an apito (whistle), and the instrumentalists and dancers then start anew, giving the singer time to prepare subsequent lyrics.

This unique dual structure, where instrumental and vocal expression have such clear separation, cannot be found in any other performance style from northeastern Brazil (Travassos 12). The mestre is accompanied by a contramestre, who always repeats the last line of a verse. There are four main genres of Maracatu Rural: marcha, samba em dez, samba curto, and galope. Each features a different rhyme scheme that influences its improvisational content. To open and to close a performance, the mestre and contramestre always sing a basic two-lined marcha.

The instrumental response is delivered by terno (percussion) and orquestra (wind instruments). The percussion consists of bombo (base-drum), taról (snare drum), mineiro (cylindrical rattle), porca or cuíca (friction drum), and gonguê (cowbell). The orquestra uses clarinet, trombone, and trumpet. The rhythm of the terno is repetitive and rapid with an average speed of $120 \mathrm{bpm}$. The wind instruments follow a similar melodic pattern, repeating the same motif for hours. When the instrumentalists take the lead, the dancers begin their performance.

\section{The Art of Improvisation}

Northeastern Brazil is known for the richness of its different rhythms and musical styles. Every poetic genre has its own unwritten rules and rhyme schemes. Historically, many Maracatu performers distanced themselves from a genre called coco by adapting their improvisational expression to the more professional style of cantoría de viola (Veloso and Basílio 48). Maracatu Rural is unique in that it has integrated and adapted both styles.

Many Maracatu poets also improvise in other styles. For my research, the coco de embolada, where two coquistas try to best each other in a poetic competition, is of great interest. Both singers perform their improvised verses over a typical coco rhythm played on pandeiro (tambourine). Coquistas entertain the audience by attacking their rivals orally through rapid rhythmic and thematic exchanges.

The funny and spontaneous elements of coco de embolada contrast with the serious and studied themes of cantoría de viola: one cannot play cantoría casually. Additionally, the rhyme scheme of cantoría is much more complex and sophisticated than that of coco (Travassos 10). Performers of cantoria improvise verses while playing the viola caipira (a guitar with five doubled strings, usually played with an open tuning that allows the guitarist to make a chord without fretting any strings). The content, variation, and improvisation of themes determines the structure of a performance, while the viola provides only harmonic background music. Focus is likewise on the dialogue between the two poets, and most rhyme schemes repeat a single meter and harmony (16).

The link between performer and audience is also very important. Normally, cantorías are performed in public spaces (a local bar or community stage) where the audience closely follows the improvised duet (Travassos 20). Spontaneity is guaranteed by a small table in front of the performers where a listener can leave a donation and a small piece of paper that contains a mote (requested theme or concept) for the singers to develop. Repeating another's lines is greatly frowned upon (21).

In regards to improvisational content and form, Maracatu Rural was, in its beginnings, much closer to the demands of coco de embolada. Loose rhyme schemes and humorous personal attacks on relatives were the norm (Ayala 63). Only in the 1990s was there a poetic switch to the more sophisticated and tactful structures of cantoria de viola. ${ }^{2}$ This turn was closely linked to Maracatu's new presence in national Brazilian media, where vulgar defamation of women and family members was not tolerated. Unlike in cantoría, however, Rural poets did not become entirely beholden to audience demands: they seek, of course, the fame of positive reviews but remain free to reject requests and frustrate expectations.

\section{Improvisation as Social Practice}

In Maracatu Rural, improvisation is a complex and contradictory concept with many ambiguous interpretations that are easily misunderstood. Maracatu singers mostly draw upon two kinds of poetic resources: memorized verses called balaio or decoração and improvised lines known as improvisado or feito na hora. Every poet depends on a variety of set phrases and prepared rhymes as insurance against awkward pauses during performance (Travassos 10), and some write their most important lines down in a caderno (small booklet). According to Mestre Barachinha, a performer has three culturally acceptable options: to improvise freely; to chant internalized lines; or to combine these two elements (Veloso and Basílio 49). 
In his introduction to In the Course of Performance: Studies in the World of Musical Improvisation, ethnomusicologist Bruno Nettl states that what "sets off improvisation from composition, and that helps the understanding of the improvisatory processes of individual performances as well as established practices, involves the identification of a point of departure (for which the term 'model' has been used) which the improviser uses as a basis for his or her art" (13). The point of departure for Maracatu Rural is the strict rhyme scheme of each poetic style, even while poets are free to choose almost any theme (Amorim 70-71). Ideally, one sings mainly about contemporary issues and does not repeat oneself, as it is crucial that audiences experience original material (Veloso and Basílio 49)_-but even though improvisation is stressed among poets as the main goal, one can consciously decide to omit it. For this reason, improvisational practice does not exist independently from the social influences surrounding it. German sociologist Roland Kurt suggests that we focus less on the creative and original aspects of improvisation and concentrate more on the social agency of the performer, and that when we discuss improvisation as social practice, we consider the cultural conditions, social position, and individual development of the social agent (39-40).

Maracatu Rural is strongly influenced by the circumstances of the moment: every verbal outcome needs to fit with the context of the current audience. Furthermore, singing is not the only attraction of Maracatu Rural. The whole performance is more like a big festival where poets, through their improvisations, inspire participants to celebrate and support the dancers intellectually and emotionally. To folk-rock singer Siba, "Maracatu is a carnival procession. For this reason, this kind of poetry is made for the street and for the dancing people: the mestre sings to animate the caboclos to dance and for the surrounding audience who participates in the feast" (qtd. in Lacerda).

\title{
The Situational Context of Improvisation
}

Theoretically, singers could simply chant ready-made verses, without taking any risk, so long as they do not repeat any to the same audience. Zé Galdinho-a local improvisation hero in Pernambuco-affirms that a good poet keeps inventing new lines for each performance. An experienced and talented mestre is able to improvise in all four Maracatu settings: each one challenges the poet's abilities in different ways. Nowadays, singers frequently move between local performance sites and regional or national ones: standards and expectations are produced by and oscillate between these two poles.

\section{Sambadas (Improvisation Duels)}

Sambadas start traditionally in mid-September, six months before the official opening of the carnival. Such duels take place in one of the mestre's hometowns, close to his or her group's sede (a small room, usually a garage), where they store all the material and costumes (fantasia) for the carnival. Some sedes have small altars or religious artifacts from the Afro-Brazilian religions catimbó or jurêma. The audience consists of undisguised performers (caboclos de lança), dancers, the regal courts of the opposing Maracatu groups, members of the local community, neighbours, and even politicians. A few outside visitors may include artists searching for inspiration, researchers, journalists, and tourists. Most bring cameras, recorders, and microphones to capture these fugacious moments of spontaneity. A solemn atmosphere pervades as people eagerly await the poets' improvisations. The duel starts around 10 pm in front of a corner with microphones where the two poets stand pé de parede (side by side) surrounded by wind instruments and percussion, while the rest of the crowd gathers around in a half-circle. A pick-up truck with loudspeakers on the roof is located behind the audience to provide amplified sound. From that moment until dawn, the participants keep dancing, drinking, listening, and performing.

The hosting mestre begins by thanking and welcoming everybody. The combatants then perform the simplest and most poetic genre of Maracatu: the two-lined marcha. Its structure, with one rhyming couplet, perfectly complements the phrases where the mestres greet participants—and often ask for cachaça (sugar-cane rum):

\author{
Muito obrigado João Paulo \\ que é poeta sambador \\ Thanks to João Paulo \\ muito obrigado pelo convite \\ que por mim vocé mandou \\ Who is a "sambador" poet \\ Thanks for the invitation \\ The one he sent to me \\ (Performed by André de Lica on 19 February 2011 during an ensaio in Nazaré da Mata.) ${ }^{3}$
}

This example shows how easy it is to improvise within this genre, relating the content to the specific moment: the same verse could be used, with appropriate names, by every poet present. After these warm-up marchas, the mestres proceed with a genre called samba de dez, a ten-line verse used to develop more complex and sophisticated themes (the rhyme scheme is ABBAAC:CDDC). This form supports the narration of short stories with added 
commentary on contemporary themes, such as the Egyptian revolution in 2011 or the football World Cup held in Brazil in 2014. The last word to be rhymed is the most important because it resonates afterwards. Not surprisingly, these key words often allude to the cultural specificity of Maracatu: Maracatu, Maracatu Rural, Cultura Brasileira, Cultura Popular, Terra de Nazaré, and so forth. Given this complex structure, many mestres tend to prepare these ten-lined verses in advance, instead of risking public failure:

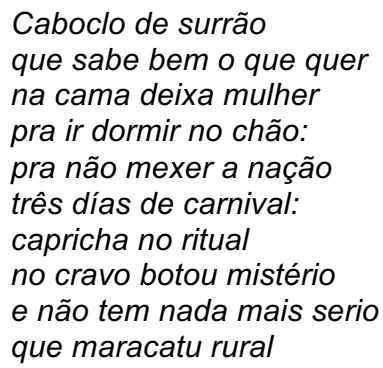

(Performed by Mestre Barachinha on 8 March 2011 during a concurso in Recife.)

\begin{abstract}
Caboclo with his cowbells knows exactly what he wants leaves his wife at home to sleep elsewhere on the floor in order not to offend his nation three days of carnival: he exerts himself for the ritual in the clove he keeps a secret there is nothing more serious than Maracatu Rural
\end{abstract}

The above verse contains images of Maracatu Rural that do not exist anymore, but it fits the exotic expectations of a foreign audience and is so well designed that I recorded the same verse quoted above over and over again in 2011 , and again in 2014 when I met Mestre Barachinha for the last time. Additionally, this example shows us how form influences content and affects a poet's decision to either prepare beforehand or take performance risks (improvise).

Around 2 am, the performers switch to a shorter and faster poetic style called galope. The instrumental parts become shorter, and thus the poets have less time for preparation. Galope is a style that allows poets to show off their improvisational skills. The atmosphere, acclamations of the audience, and content of the improvised verses all become more vivid and aggressive:

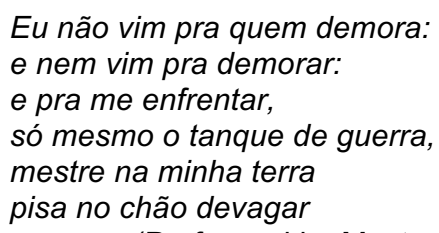

I didn't come for those who need much time,

Neither came I to stay

Only a war tank

Can compete with me

The mestres of my region

Are too slow

Given the short metrical structure of the galope and the speed at which it must be sung, poets have little chance to remember their verses afterwards. At the climax of a duel, only a few seconds of musical break separate each poet's performance. In this scenario, the mestres can trust only in their skill to produce spontaneously new rhyming combinations. Similar styles performed in the heat of the night are called samba em seis or samba curto (the latter almost identical to other short verses, except that the first line has only four syllables).

The sambada finishes as soon as a poet starts anew with a two-lined marcha, reciting set-phrases this time thanking everybody and announcing the end of the duel. If both singers endure the whole night, each gains prestigio (prestige) and fama (reputation) among the Maracatu community.

There is no objective judge who decides who wins and loses (Veloso and Basílio 50). To successfully rhyme all night in front of such an expectant crowd (who are drinking, dancing, and shouting during the whole performance) requires great knowledge and talent. The length of the performance, in particular, forces one to improvise, as a poet cannot repeat the same line twice. Such display is all about showing one's capacity to sing about almost anything: science, sports, religion, and the like. Zé Galdinho revealed to me that one can prepare verses for two or three hours, but it is impossible to memorize lines for more than ten hours of singing. Poets need to face the sambada with a vast repertoire internalized through significant practice: dueling requires improvisation to answer the provocations and allusions of one's counterpart.

Mestre Barachinha told me about the first time in his career when he was forced to improvise: 
To this day I cannot forget that verse; it was a line that said the following: "on the day you were born, there was the biggest confusion, your brother already awaited you to teach you to sing" . . . this means he forced me to improvise and I didn't know what to say, but I somehow had to escape the situation.

Apart from the pressure to answer a challenge from an opponent, the poet runs the risk of xitação (malicious gossip) when improvising. According to the young mestre André de Lica, improvisation requires considerable confidence and experience:

I can only participate in a sambada when I have gathered enough experience within Maracatu, because one has to stay afoot the whole night . . . there are many drunk people . . . and all these insults . . the one who sings more beautifully and is better at rhyming will succeed.

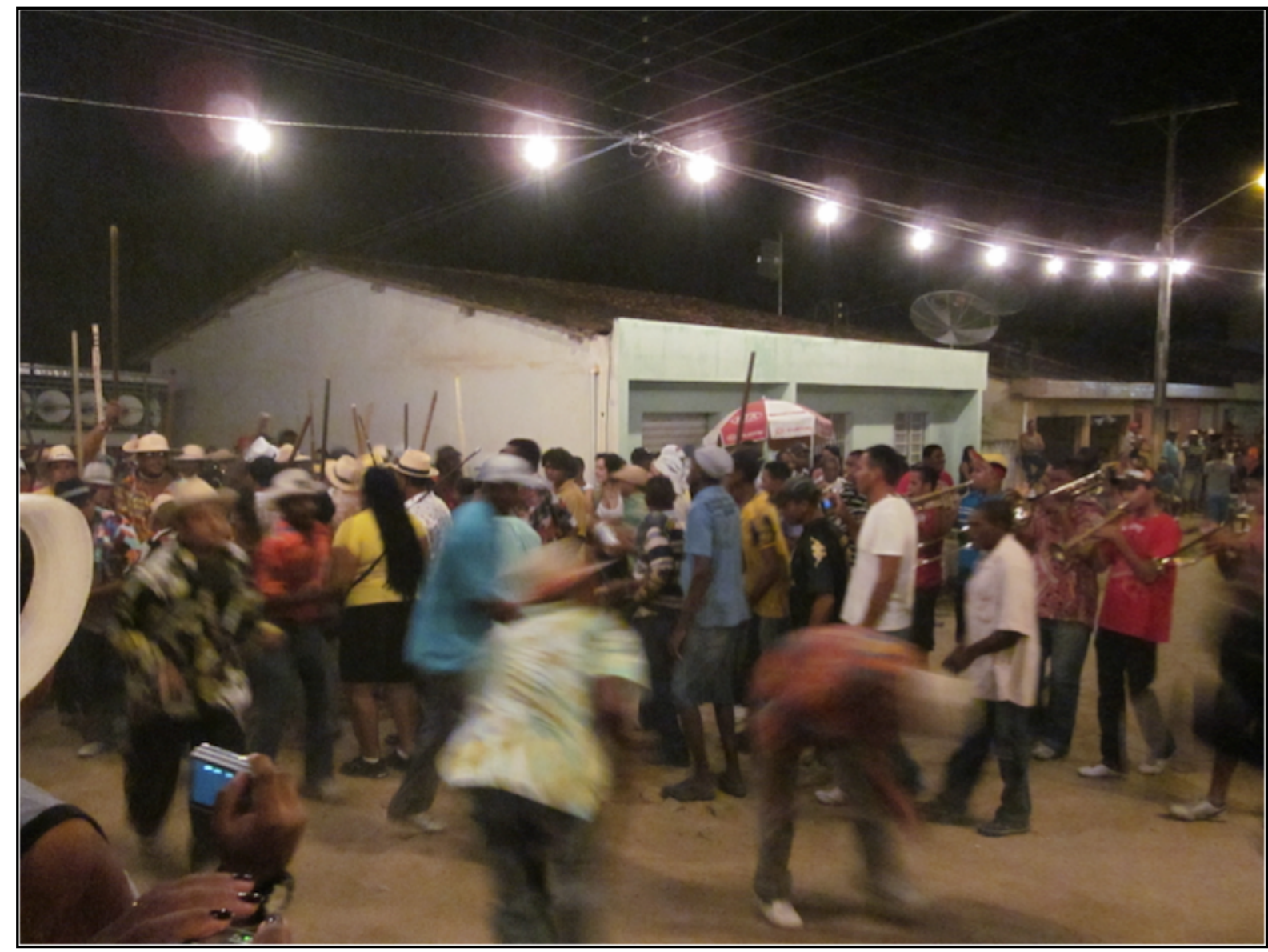

Having successfully passed several sambadas, an improvising poet can build upon his fame. Ensaio of Maracatu Leão Misterioso in Nazaré da Mata. Caboclos shown here are dancing without their carnival costumes. (19 February 2011)

\section{Ensaios (Rehearsals)}

Ensaios are similar to sambadas, but only one poet sings at a time. The hosting Maracatu group organizes a party and invites other mestres. Depending on fame and financial possibilities, the number of participants can vary from twenty to more than a hundred. Ensaios are useful for musicians, poets, and dancers, as they can practice for the carnival competition where they would lose points for any uncoordinated steps. After the opening, performed by the hosting Maracatu group, the mestre goes through many poetic styles (marchas, samba de dez, galope) for as long as desired (usually about one hour). After that, other poets are invited to recite their verses based on their preferred styles and themes. Many poets perform until the host mestre, by tradition the first and last singer, concludes the performance at dawn. 
These rehearsals are the perfect setting for young poets to practice improvising and display to a critical audience their capacities as mestres (Veloso and Basílio 50). Compared to sambadas, ensaios do not encourage improvisation because one is not forced to answer the provocation of an adversary, and one hour is time enough to prepare verses. Rehearsals are far more important as times to prepare and test lines for the carnival. Ensaios emphasize having fun and making people dance. Under such circumstances, it is difficult to determine if someone is improvising or not: every verse that references the moment of the performance is regarded as improvised. In addition, many poets will comment on circumstances like a sudden change of weather or a malfunctioning microphone, as I have observed during my research:
O Pessoal tâ correndo
People are running
estou no pé da biqueira:
I'm staying at the foot of the rain pipe
é a pé no sereninho
que é para baixar a poeira
I'm walking in the morning dew
Oh take off the dust

(A marcha performed by João Paulo on 19 February 2011 during an ensaio in Nazaré da Mata.)

\section{Apresentações e Concurso (Presentations and Competition)}

Most apresentações take place during the first three days of carnival (Veloso and Basílio 51). A busy schedule means a lot of pressure to be on time at different places. Every town has a palco (stage) where groups perform one after another: the large number of participating groups allows for no more than 20 minutes per presentation, and each poet has only about 15 minutes to sing. Such an atmosphere does not support improvisation, either in form or content. Usually, poets choose two-lined marchas to thank the local politicians for their financial support (Veloso and Basílio 51):

on the stage time is always limited; the atmosphere of the FCP (carnival organization) creates a certain obligation to fire off loas for the authorities and the politicians; "One sings two marchas, two sambas and then goodbye." (Coehlo de Souza qtd. in Amorim 66)

The visual presentation of colourful costumes and dancing is the center of attention, but the concurso is the highlight for Maracatu groups because of the prize money and potential prestige. Here, poets must demonstrate their skills in each of the poetic styles of Maracatu. The pressure to avoid even the slightest mistake is enormous: Mestre André de Lica points out that

similar to the rehearsals, the poet performs during the carnival; when he comes to the competition he is already prepared ... he goes there prepared, because he is judged by the commission; when he messes up with a verse, he loses points; that's the main difference from the rehearsal.

But carnival presentations bear another risk: a poet from the countryside has to sing in front of a foreign crowd of tourists and city-dwellers and fulfill their expectations of an exotic folk-play. Poets are also eager to portray themselves as educated, so prepared verses are therefore useful in order to rhyme exotic metaphors for outsiders in properly pronounced Portuguese.

While these latter settings, organized by the government of Pernambuco, are becoming more and more important because of the financial support they give to Maracatu Rural groups, traditionally celebrated gatherings such as the sambadas and the ensaios have declined because of the high costs involved. These external forces have reduced the practice of improvisation, while the preparation of verses has become more important in order to face an increasingly unknown audience. 


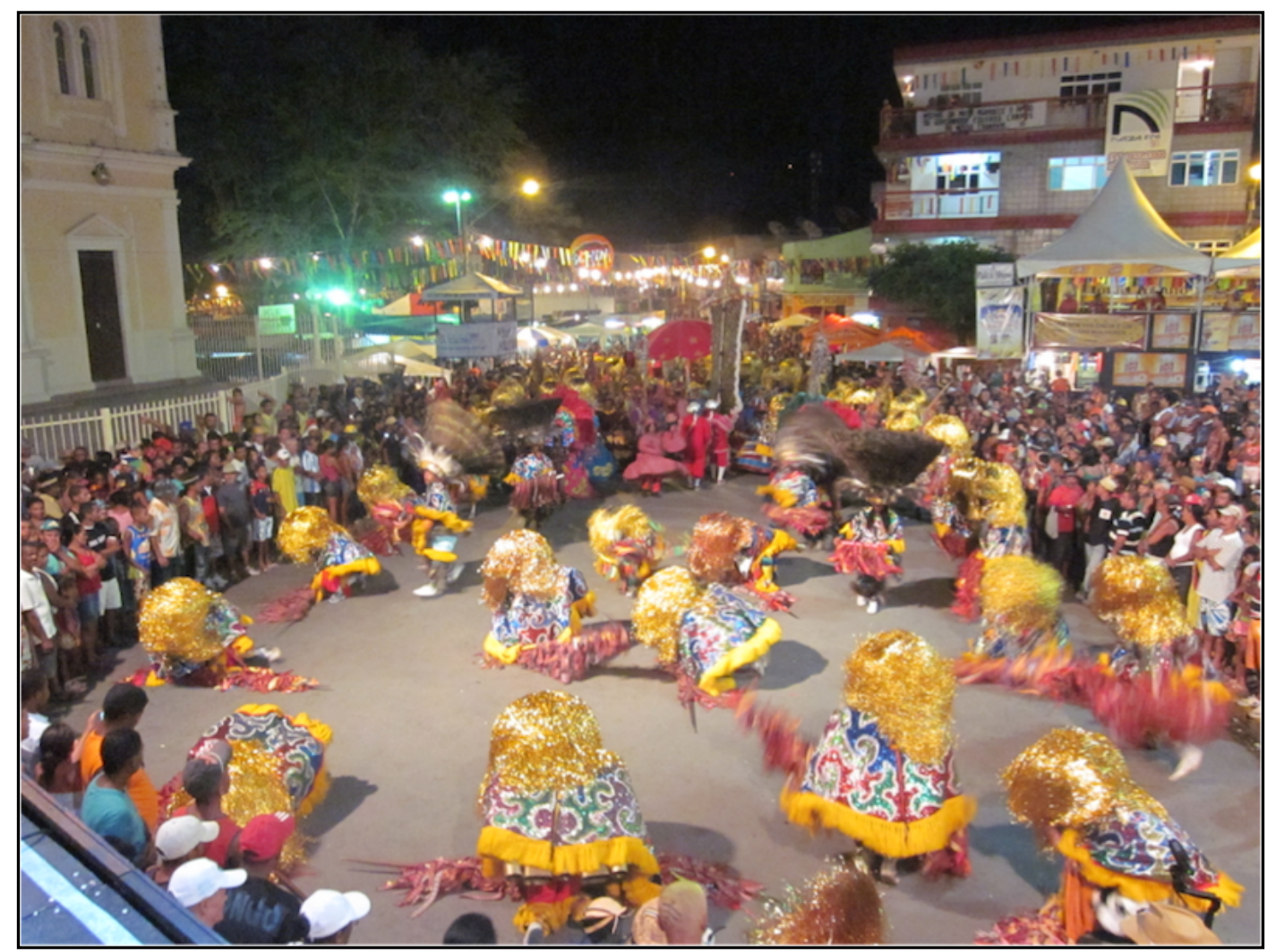

The last apresentação of Estrela Brilhante in Nazaré da Mata (9 March 2011)

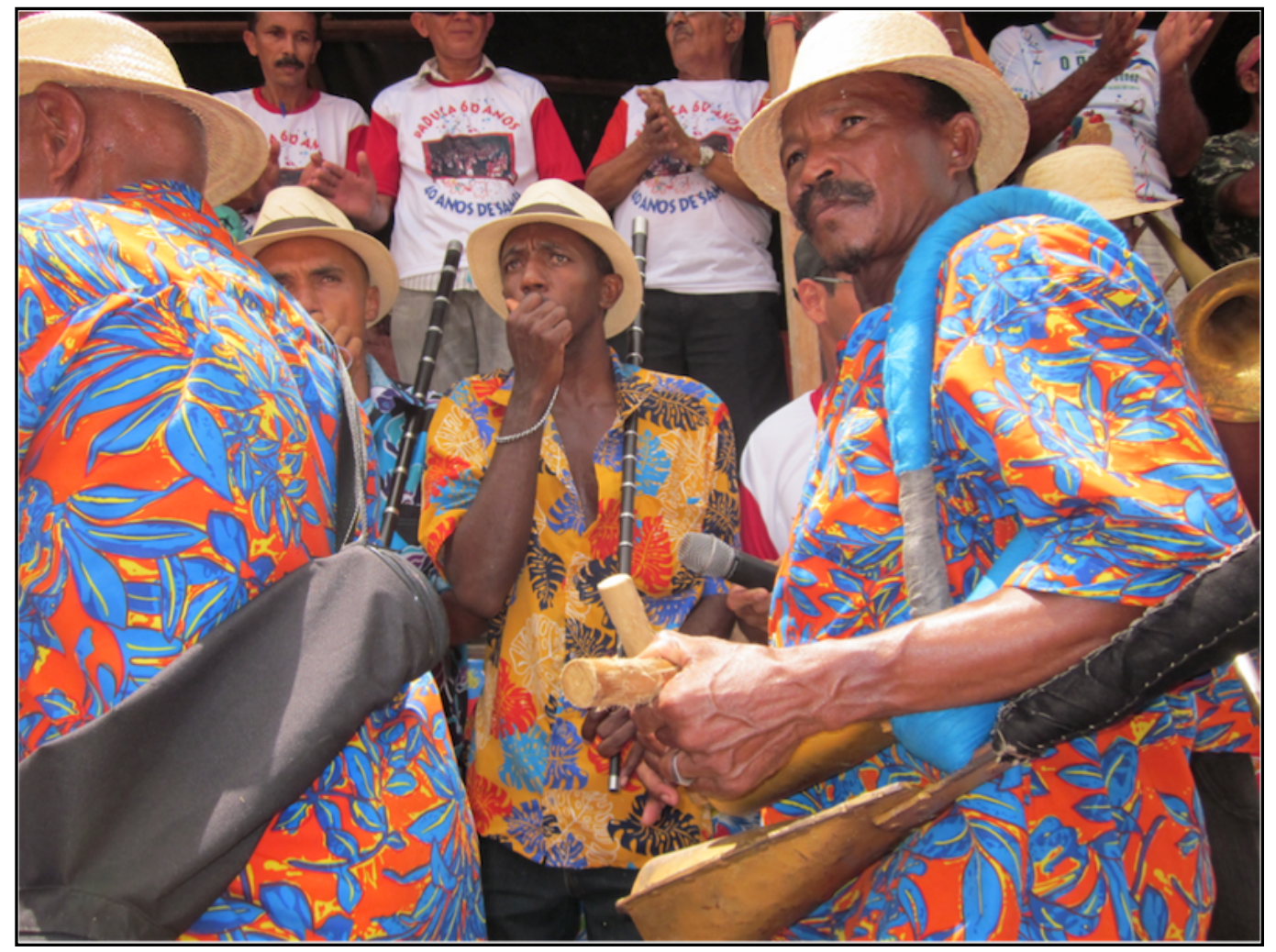

Mestre Barachinha supporting his dancers with his apito while preparing the next verse. Apresentação in Lagoa Itaenga (7 March 2011). 


\section{Summary}

Improvisation is not practiced by all mestres nowadays with the younger generation especially preferring to prepare verses. This change in practice should not be evaluated negatively, as pre-composition of verses is a legitimate option within Maracatu Rural. Of greater concern is the decline of sambadas and ensaios as performance settings where young poets can actively learn the art of improvisation. Compared to the past, it is now easier to study improvisation through modern media than in performance; as a consequence, many consider themselves as mestres without having participated even once in a sambada duel. For short presentations, one can simply prepare some short verses (two-lined marchas) to thank the political authorities. The support of gente da cultura (people of culture) is welcome given the high unemployment in the region, but this recent shift towards truncated public presentations with less focus on improvisation can be dangerous to the art form if the sambadas and ensaios are not supported.

My concern is not about privileging one performance style over another, but more about free and fair access to resources and modern technologies necessary to create autonomous cultural productions. This requires the appreciation of the poet's cultural identity by the broader civil society of Brazil, as Brazilian philosopher Marilena Chauí addresses in "Politische Kultur und Kulturpolitik" when she speaks of the "right to culture" (199). Producers of cultura popular need to recognize open access to information, formal and informal spaces, and public institutions as key conditions of their interdependency with the state. As Zé Galdino suggested to me during an interview in January 2011 , only when poets can decide independently where and when to perform can they use the main weapon they possess-improvisation.

The repetitive musical patterns and seemingly wild, uncoordinated dancing of Maracatu Rural captures the public's attention, allowing for cultural and political dialogue between different members of Brazilian society-dialogue shaped through historical dependencies, ethnic conflict, and structural racism. Improvisation challenges a common stereotype of sugar-cane workers as uneducated, illiterate, and representative of a long forgotten past. These artists have adapted their craft to the social norms of modern Brazilian society by promoting peaceful collaboration, educated use of language, and acceptance of outsiders.

Brazil is experiencing a new period of á mestiçagem, a conscious merging of different cultural heritages into new hybrid forms of cultural expression once summed up by Oswald de Andrade as an "anthropophagic being." Maracatu Rural improvisation is thus living proof of an image of Brazilian "folklore" in constant change, change that shows how variable and culturally dependent improvisatory practices are.

\section{Notes}

${ }^{1}$ One prominent forum is Rádio Alternativa, 98.5 FM: www.alternativafmamunam.blogspot.com.

${ }^{2}$ For example, a ten-line verse called samba em dez (Veloso and Basílio 53).

${ }^{3}$ All English translations of lyrics here and throughout by the author.

\section{Works Cited}

Amorim, Maria Alice and Roberto Benjamin. Carnaval: Cortejos e Improvisos. Fundação de Cultura Cidade de Recife, 2002.

Assis, Maria Elisabete Arruda. Cruzeiro de Forte: A Brincadeira e o Jogo de Identidade em um Maracatu Rural. Dissertação de Mestrado Apresentada ao Programa de Pós-Graduação em Antropologia da Universidade Federal de Pernambuco, para obtenção do Grau de Mestre em Antropologia, 1996.

Ayala, Maria Ignez. "Coco de embolada: mágica na palavra e no pandeiro." Na ponta do verso-Poesía de improviso no Brasil, edited by Axandre Pimentel and Joana Corrêa, Associação Cultural Caburé, 2008, pp. 58-73.

Barachinha, Mestre. Personal Interview. 4 Feb. 2011.

Baumann, Richard. "Verbal Art as Performance." American Anthropologist, vol. 77, no. 2, 1975, pp. $290-311$. 
Béhague, Gerard. "Introduction." Music and Black Ethnicity: The Caribbean and South America, edited by Gerard Béhague, Transaction Publishers, 1994, pp. v-xii.

---. "Performance and Listener-Centered Approach to Musical Analysis: Some Theoretical and Methodological Factors." Latin American Music Review / Revista de Música Latinoamericana, vol. 27, no. 1, 2006, pp. 1018.

Chauí, Marilena. "Politische Kultur und Kulturpolitik." Brasilien: Land der Zukunft?, edited by Rafael Sevilla and Darcy Ribeiro, Horlemann, 1995, pp. 187-201.

De Lica, Mestre André. Personal Interview. 26 Feb. 2011.

Finnegan, Ruth. Oral Poetry: Its Nature, Significance and Social Context. Cambridge UP, 1977.

Hannerz, Ulf. Cultural Complexity: Studies in the Social Organization of Meaning. Columbia UP, 1992.

Kurt, Roland. "Komposition und Improvisation als Grundbegriffe einer allgemeinenen Handlungstheorie." Menschliches Handeln als Improvisation, edited by Ronald Kurt and Näumann Klaus, Transcript Verlag, 2008, pp. 17-46.

Medeiros, Roseana de Borges. Maracatu Rural: luta de classes ou espetáculo? Fundação de Cultura Cidade do Recife, 2005.

Lacerda, Hilton, dir. Poetas de Repente. YouTube, 2006, www.youtube.com/watch?v=J8jHFvmtTNw\&feature=related.

Nettl, Bruno. "Introduction: An Art Neglected in Scholarship." In the Course of Performance: Studies in the World of Musical Improvisation, edited by Bruno Nettl and Melinda Russell, U of Chicago P, 1998, pp. 1-26.

Sandroni, Carlos. "O mangue e o mundo: notas sobre a globalização musical em Pernambuco." Claves, vol. 7, 2009, pp. 63-70.

Silva, Severino Vicente. Festa de Caboclo. Editora Associação Reviva, 2005.

Stanyek, Jason. "'A Thread that Connects the Worlds': Ovoid Logics and the Contradictory Lines of Force of Brazilian Improvisations." Critical Studies in Improvisation / Études critiques en improvisation, vol. 7, no. 1, 2011.

Travassos, Elizabeth. "Prefácio: ABC do verso na ponta da língua." Na ponta do verso-Poesía de improviso no Brasil, edited by Alexandre Pimentel and Joana Corrêa, Associação Cultural Caburé, 2008, pp. 9-13.

Veloso, Siba and Astier Basílio. "Samba Novo: a poesia do maracatu de baque solto." Na ponta do verso-Poesía de improviso no Brasil, edited by Axandre Pimentel and Joana Corrêa, Associação Cultural Caburé, 2008, pp. 44-57.

Vicente, Ana Valéria. Maracatu Rural: o espetáculo como espaço social. Editora Associação Reviva, 2005. 